\section{Progress in Seismology}

THE forty-first report of the British Association Cornmittee on Seismological Investigations includes many points of interest. A brass sphere, 18 inches in diameter, has been made by Messrs. Casella for use in the determination of epicentral distances. The positions of observatories are marked by holes and the sphere has been chromium-plated. The Committee is indebted to Mrs. H. H. Turner for providing most of the accessories that will be used in ascertaining the distances and azimuths of the epicentres. Four small earthquakes were felt in the British Isles since the last report was presented, in the Channel Islands and at Leigh, Comrie and Kinlochewe. The earthquakes in the island of Montserrat continue, though they were less frequent during the first half of 1936 than in the two preceding years. A Wiechert horizontal seismograph has been installed, in addition to a number of Jaggar shock-recorders that were made at Kow Observatory for the use of the expedition sent out by the Royal Society. The preparation of the International Seismological Summary for 1931 has been completed, and the sections for the first half of the year have been printed and distributed. The number of earthquakes included is 297. References are also made to Dr. H. Jeffreys' revised table of transmission times recently published by the Bureau Central de Séismologie, to the unusually long seismic waves associated with the South Pacific earthquake of June 26, 1924, and to the Baffin's Bay earthquake of November 20, 1933.

\section{Megalithic Monuments of South Wales}

THE latest addition to the Megalithic Survey of England and Wales ("Map of South Wales showing the Distribution of Long Barrows and Megaliths". Compiled by F. W. Grimes. Southampton : Ordnance Survey. Pp. 56 and Map : Scale 4 miles to 1 inch. 58., 58. $6 d$. and $6 s .6 d$. net) incorporates the results of a survey of the area covered by Sheet 7 of the Quarter-inch Ordnance Map. It is now possible for the first time, as the Director-General points out in an introductory note, to assess the distribution of the megalithic monuments of an area which has been recognized as an important centre of the culture. This region, predominantly upland, and, therefore, differing essentially from others already covered by the series, falls into two parts, a narrow coastal plain of undulating country, seldom more than $400 \mathrm{ft}$. above sea-level, in which the monuments are mainly found, and an upland, which attains its greatest heights in Brecknock Beacons, and of which a large part is above the $1,000 \mathrm{ft}$. contour line. Mr. Grimes discusses a number of questions arising out of the distribution of the monuments, not the least interesting being those relating to his omissions, a matter with which he proposes to deal at greater length elsewhere. He also raises a question of wide general interest in connexion with Stonehenge. One of the most noteworthy contributions to British archæology of the post-War years was the conclusion, at which the late Mr. H. H. Thomas of the Geological Survey arrived in 1923, that the blue stones of the inner circle at Stonehenge were igneous rock derived from the Presely Mountains and the altar stone micaceous sandstone of either the Cosheston Beds around the estuary of Milford Haven, or the Senni Beds of Carmarthen and Brecknock; but up to the present no satisfactory hypothesis as to the method of transport and route has been offered. Mr. Grimes discusses the question in the light of his survey and gives his reasons for suggesting a route by both land and water in which transport from the Presely Mountains to the sea was effected by one of three possible ancient roads which he shows.

\section{Aleutian Islands' Skull of Abnormal Size}

DR. Areß HRDLIČKA, it is reported by the Smithsonian Institution, Washington, D.C., in the course of excavations on the Aleutian Islands, has brought to light a skull of remarkable size. Its cubic capacity is said to be no less than 2,005 c.c. This is the second highest skull capacity recorded, the largest being that of Turgenev, the Russian novelist, whose skull has a capacity of 2,030 c.c. Skulls of known capacity ranking next are those of Daniel Webster, 2,000 c.c., Bismarck, 1,965 c.c., La Fontaine, 1,950 c.c., Beethoven, 1,750 c.c. and Kant, 1, 740 c.e. The enormous, but imperfect, South African Boskop skull, according to one estimate, has been rated at 1,950 c.c.; but a more conservative figure places it round about 1,700 c.c. Dr. Hrdlička's excavations on the Aleutian Islands, in the course of which the present find was made, are in continuation of a series of investigations of the archæology and physical anthropology of the present and former inhabitants of Alaska and the adjacent islands, upon which he has been engaged on behalf of the Smithsonian Institution for successive seasons during a number of years. His object is to elucidate the racial affinities and chronological succession of the early peoples who migrated from north-eastern Asia to populate America. On this problem, unfortunately, his latest discovery, apart from the probability that it is no more than an individual instance of abnormal development, would appear to throw no certain light, owing to the absence of the facial skeleton.

\section{Human History and Geographical Discovery}

IN his presidential address to the British Academy in July last (London : Oxford University Press. 1s. net) Mr. J. W. Mackail said that we are at the beginning of a new era of discovery and interpretation which is revolutionizing the whole aspect of human history. Civilizations of the past in every continent are yielding up more of their secrets. Byzantine history, art and institutions have emerged from comparative neglect to an important place in humane studies. The past ages of India, China and Japan and even Central Asia are revealing their significance. The greatnesses of Central and South America are taking their place in the panorama of the past, and undiscovered Africa and impenetrable Arabia no longer exist. But important as are the acquisition and tabulation of knowledge, the primary function of humanism is the appreciation, in the largest sense of the word, of the classies of art, music, philosophy, 
history and creative invention over the whole range of life as throughout the whole range of literature. The danger which menaces learning is not that of conflict of sectional interests but of a general relapse into barbarism. It is not needless to reaffirm once more our emphatic and uncompromising support of all efforts to maintain the free development of the human intellect, unhampered by autocratic interference.

\section{Avon Biological Research}

The third Annual Report, 1934-35, describing the continuation of work on the lines approved by the Avon Co-ordinating Committee, has recently been published (University College, Southampton. Avon Biological Research. Annual Report, 1934-35. Pp. $126+3$ plates. Southampton : University College, 1936. $2 s .6 d$.). The work is conducted at University College, Southampton, where there are special laboratories set aside for the purpose, and on various parts of the river ; the main purpose being salmon research and its branches, although trout research is also included. The salmon research is approved by the Development Commissioners, who since October 1934 have kept it under their official supervision, the Treasury having granted a sum towards the expenses enabling, among other things, a junior research officer to be appointed. Much help is acknowledged. Colonel Bennet-Stanford has erected a hatchery and provided facilities for the freshwater rearing of salmon in his lakes at the head waters of the Nadder, a tributary of the Avon, more than fifty miles from the sea, and many others have assisted substantially, both financially or by individual work and advice. A rotating fish screen (described in the appended papers) has been set up on Major Napier's land at Fordingbridge, where also are experimental spawning beds. East Mill still remains the headquarters of the river. The general report deals with the importance of vermin, artificial propagation and smolt migration. Appended papers include "British Mammals and Birds as Enemies of the Atlantic Salmon" (a most interesting and important summary), and "Importance of Iodine in Relation to Fish", besides accounts of hatching and stocking experiments and of scales from the Avon trout and grayling.

\section{Useful Birds}

Three new Advisory Leaflets dealing with some British birds of prey have been issued by the Ministry of Agriculture and Fisheries. One describes the appearance and activities of the buzzard, another those of the long-eared and short-eared owls; and in the case of each of these birds the decision is that it is beneficial and worthy of careful protection. The third leaflet discusses the tawny or brown owl and the little owl; while the former is regarded on the whole as doing more good than harm, the little owl, although it also destroys pests, has become too plentiful in many districts on account of the loss it causes to poultry-keepers and others, and is therefore in no need of protection. These leaflets with their excellent illustrations by G. E. Lodge should be widely distributed in schools; they form the best sort of propaganda for bird protection.

\section{Destruction of 'Vermin' in Bedfordshire}

Luton Museum has performed a useful service in publishing a summary of "Bedfordshire Vermin Payments", extracted by J. Steele Elliot from the records of parish officials during the sixteenth to nineteenth centuries. A recent note in these columns referred to the exceedingly limited distribution of the pinemarten and polecat in Britain at the present day; but up to 1808 the pine-marten was being killed, at $2 d$. a head, in Bedfordshire, and in forty-two parishes payment was claimed on a total of more than 6,000 polecats, the most recent record in these accounts being in $\mathbf{1 8 3 5}$. It is a sorry tale of extermination.

\section{Indian Wild Life : a New Magazine}

IN an effort to encourage wider sympathy with wild life in India, a group of enthusiasts has published Indian Wild Life, the official organ of the All India Conference for the Preservation of Wild Life. The objects of the Conference are ambitious : to give effect in all parts of India to the provisions of the All India Convention of 1935, to encourage the preservation of fauna and flora, popularize natural history in schools, establish a natural history library, and an exchange system of literature, to establish a National Park and to publish books and pamphlets on Indian natural history, and to disseminate literature in different languages. It is a big programme, but it is worth aiming at, and well worth encouraging. To the mind of a Western reader, too great a part of the new magazine is given up to personal paragraphs, but it is encouraging to find that already one of its objects has been fulfilled, and that a United Provinces National Park is an accomplished fact-the only Park of its kind in India.

\section{British School of Archæology at Rome}

IT is announced that Mr. C. A. Ralegh Radford has been appointed director of the British School of Archæology at Rome in succession to Mr. Colin Hardie, recently appointed fellow and classical tutor of Magdalen College, Oxford. Mr. Radford is a former student of the British Schools of Archæology at both Athens and Rome; and by his excavations on prehistoric Roman and medieval sites in Britain and abroad has taken a prominent part in recent advances in archæological studies. He was appointed Inspector of Ancient Monuments for Wales and Monmouthshire in 1929, and is also a member of the Royal Commission on Ancient Monuments of that area. As general secretary with Prof. V. Gordon Childe of the First International Congress of Preand Protohistoric Sciences he was jointly responsible with him for much of the success of the session held in London in 1932. Mr. Radford's training and experience have been such as should enable him to preserve the necessary balance between the studies of the School in prehistoric, protohistoric and classical archæology, to which the special eircumstances of Rome are perhaps less conducive than those of Athens. 